\title{
Research on the English Reading Teaching Based on Flipped Classroom
}

\author{
Xiaoyan Zhan \\ School of Foreign Studies, Huanggang Normal University, Huanggang 438000, China \\ 516556446@qq.com
}

\begin{abstract}
With the development and popularization of online courses such as MOOC and flipped classroom, the traditional reading teaching model can't meet the needs of English reading teaching. By analyzing the shortcomings of traditional reading teaching, this paper explores the superiority of English reading teaching and the realization of flipping classroom and proposes an English reading teaching model based on flipping classroom which can provide a reference for the reform of college English reading teaching.
\end{abstract}

Keywords: English reading; flipping classroom; teaching model.

\section{Introduction}

The English Extensive Reading Course is a major course for the first and second grades of English majors. The "Syllabus" proposes that "the teaching method of professional courses is directly related to the cultivation and improvement of students' ability in all aspects. Classroom teaching should take students as the main body and teachers as the mainstay to change the past teacher-centered teaching model to focus on cultivating students' learning ability and research ability." [1] Therefore, on the one hand, teachers should change their teaching philosophy, and change the teacher-centered teaching model to focus on students to develop students' self-learning and independent reading ability. On the other hand, the characteristics of the English extensive reading class also determine that students should choose a wide range of materials outside the classroom, increase the amount of reading, and read independently. The traditional English reading course teaching model, which focuses on reading skills training and the understanding of target language and reading speed training, has faced serious challenges. The flipped classroom teaching model is a subversion of the traditional classroom. It has been widely concerned around the world since 2011, and the domestic research boom has also started. The combination of flipping classroom theory and English reading courses can make students' reading style more free, reading richer more prominent.

\section{Definition of the Flipping Classroom Model and Related Research}

"Flipping the classroom" is simply a way of reversing the traditional knowledge transfer and knowledge internalization, that is, the knowledge transfer is placed outside the classroom by the students, and the internalization of knowledge is put into the class (Zhang Jinlei et al. 2012) [2]. Enfield (2013) obtained a specific understanding after selecting two classes at California State University Northridge to try to flip the classroom teaching: before the class, the teachers provided students with teaching resources including paper learning materials and multimedia materials and students learn independently with Information Technology. While in the class, students use the knowledge learned before class to analyze doubts, difficulties and key points and solve some challenging problems. Teachers and students communicate, and students learn collaboratively to cultivate students' ability to use knowledge thinking [3]. In recent years, the flipping classroom model has become more and more popular among foreign educators. With the development and popularization of information network technology, the flipping classroom model has gradually been applied to the teaching of middle schools and universities. In the aspect of localization reform of the flipping classroom, Prof. He Kekang analyzed the origin, development, effects and the limitations and challenges faced in the implementation of the classroom, and deeply discussed the essential characteristics of the flipping classroom, which proposed clear direction of the flipped classroom 
development in China [4]. Dr. Zhao Xinglong compares the flipping classrooms in international and domestic contexts, and combines the national conditions from the macro, medium and micro perspectives to design the flipping classroom teaching model [5]. In the aspects of designing Flipped classroom stage and attracting students' attention, Zhang Jinlei put forward the three-stage theory of flipping classroom and designed the teaching model of flipping classroom based on the concept of game-based teaching [6].

\section{The Problems of Traditional Reading Teaching}

Although the extensive reading class is a compulsory course in the basic stage of college English major, its status quo is not optimistic. The problems in the extensive reading class are mainly reflected in the teaching materials, teaching methods, students' extracurricular reading and teachers' examination of extracurricular reading. First of all, although the content of the textbook is widely selected, it cannot meet the requirements of a large number of students for reading due to space limitations. Secondly, there are only 2 hours per week in the class; the time for extracurricular reading is far from enough to ensure that the amount of reading. It is also difficult for teachers in the class to teach students in accordance with their aptitude and individualized teaching. The defects of the first two steps make students unable to construct meaningful knowledge and cannot form their own knowledge system. In the face of large class teaching, the teacher can't check the students' extracurricular reading. This does not meet the requirements of the syllabus for the extensive reading, and the teaching objectives of the extensive reading have not been implemented.

\section{The Advantage of Flipping the English Reading Course}

(1) Flipping English reading class is conducive to improving reading speed and expanding vocabulary. In the classroom model, teachers can select multiple articles with uniform theme and model rate length to be made into courseware or e-books. The reading speed of the students enables the students to independently study the reading skills. At the same time, each video can be paused and played back, which is convenient for students to control themselves. The words and difficult sentences after each article help students understand their learning effects, adjust their learning status, and clear language barriers for classroom activities.

(2) Flipping the English reading class is conducive to the development of classroom teaching. Although extracurricular video teaching is a major feature of flipping classrooms, the effective and face-to-face interaction between teachers and students in class is the charm of flipping classrooms. Extracurricular "information transfer" strives for the "absorption internalization" in the class. In addition to teaching reading skills, teachers need to carefully design classroom activities suitable for reading topics and student level.

(3) Flipping the English reading class is conducive to the application of critical reading strategies. The traditional reading model emphasizes the teaching of language skills. The purpose of reading English articles is not limited to the understanding of discourse, but also appropriate evaluation of discourse, that is, critical reading.

\section{The English Reading Teaching Model based on Flipping Classroom}

Flipping the classroom achieves the reversal of knowledge transfer and knowledge internalization. The transfer of knowledge in the traditional classroom is transferred to the pre-course completion, and the internalization of knowledge is transferred from the activity of the original homework to the learning activity in the classroom. The flipping classroom teaching model is applied to the English reading teaching. The specific operating procedures are as follows: 


\subsection{The Teacher Prepares the Micro Video Before the Class.}

In the flipped classroom teaching, the intake of students' knowledge is mainly accomplished by watching the videos made by the teachers. Before the class, the teachers design teaching video materials according to the teaching objectives, teaching focus and the online high-quality open educational resources. The micro-video content of the English reading class is mainly the overall analysis of the text and the introduction of related background knowledge.

\subsection{Students Watch the Instructional Videos and Complete Targeted Exercises before Class.}

When students watch the instructional videos at home, they should pay attention to the results of their own videos and the problems they encounter. In the pre-class learning process, teachers and students can use the qq group platform to communicate. Students can interact with classmates through message boards, chat rooms and other network communication tools at home to understand the gains and doubts between each other.

\subsection{The Teacher Determines the Problem of Class Discussion}

Before the class, the teacher summed up and designed some questions with inquiry value according to the reading text materials, the questions raised by the students when watching the videos, and the problems in the pre-class targeted exercises, such as the topic of the article, character analysis, and article writing features. Students choose the appropriate inquiry questions according to their own understanding and hobbies during class, and then the teachers group students according to the students' selected questions. Since most students do not like English reading at all, the problems and tasks designed by teachers must be interesting, purposeful and hierarchical. This ensures that every student participates in the classroom and has tasks to do.

\subsection{Independent Reading}

After selecting the discussion questions, the team members should first independently read and think independently. Students can use the network resources to carry out a large number of independent reading to improve their reading level. Students watch the video and read the materials to complete the reading task to cultivate the students' self-learning ability.

\subsection{Team Members Learn Cooperatively}

After the students' independent exploration, the group members will cooperate and exchange learning. The cooperative learning can be in the form of dialogue, discussion or argument. In the process of student discussion and communication, the teacher must pay attention to the discussion of the students and give timely guidance.

\subsection{Reading Results Display}

After independent reading and group study, the students will display the results of the reading. The results will be displayed in each group. One or two students will express their group's views on a certain issue. Since the group has more time and limited time, the results should be concise and clear, and strive to make every group have the opportunity to show on stage.

\subsection{Reading Feedback}

The flipping classroom teaching model focuses on the diversity of learning evaluation. Teachers should not only pay attention to the evaluation of students' learning results, but also evaluate and feedback on the performance of students in the process of independent exploration and the performance in group cooperative learning. Comments are not only teachers' comments on students, but also students' comments on students. 


\section{Summary}

In summary, the flipping classroom teaching model is different from the traditional teaching model and more in line with the principles of reading teaching and modern educational concepts. It can give full play to the subjectivity and initiative of students, stimulate students' reading interest, and improve students' independent reading ability.

\section{Acknowledgments}

The work is supported by the Teaching Research Project of Huanggang Normal University (No.2015CE17).

\section{References}

[1]. English group of the Teaching Guidance Committee for Foreign Languages in Colleges and Universities. English Teaching Outline for English Majors in Colleges and Universities. Journal of Chengdu University (Educational Science Edition), 2007 (11).

[2]. Zhang Jinlei, Wang Ying, Zhang Baohui. Research on flipping classroom teaching model [J]. Journal of Distance Education, 2012, (8): 46-51.

[3]. Enfield J. Looking at the impact of the flipped classroom model of instruction on undergraduate multimedia students at CSUN[J]. Tech Trends,2013,57(6):14-27.

[4]. He Kekang. From the essence of "flip classroom", look at the future development of "flip classroom" in China [J]. Electro-educational Research, 2014, (7): 5-16.

[5]. Zhao Xinglong. Design of knowledge internalization process and teaching model in flipping classroom [J]. Modern Distance Education Research, 2014, (2): 55-61.

[6]. Zhang Jinlei, Zhang Baohui. Application of game-based learning concept in flipping classroom teaching [J]. Journal of Distance Education, 2013, (1): 73-78. 